\title{
META-ANALYSIS EFFECTIVENESS OF PROBLEM-BASED LEARNING MODEL IN SOCIAL SCIENCES
}

\author{
Lubna \\ Universitas Islam Negeri Mataram, NTB, Indonesia \\ lubna68@uinmataram.ac.id
}

\begin{abstract}
This research is intended to analyze the effectiveness of problembased learning in social sciences settings. The study employed a quantitative approach using a meta-analysis method which is defined as the analysis of the same topic existing literature. This study referenced 4 out of 9 representative journals and was determined as the analysis unit. Subsequently, it is decided to make six sub-study out of four analysis unit. Glass' effect size equation is employed as the data analysis. This study revealed, (1) the overall effect of the problem-based method on the students' learning achievement standard deviation was 0,795, (2) the utilization of problem-based method showed significant result on the highly motivated and gifted students; (3) this learning method is relevant to all educational stage.
\end{abstract}

Keywords: Meta-analysis, problem-based learning model, Social Science learning, motivation, IQ.

\section{INTRODUCTION}

Social sciences refer to the branch of sciences that related to human socio-cultural aspects. This learning subject prepared students to have a sense of crisis, which is empathically responded to their surroundings (e.g, the current Covid-19 pandemic). This empathy is categorized as compassionate empathy, trying to put ourselves into someone's shoes and willingly taking action to help those who are in need. That being said, one of the main points of social sciences learning is to shape students' social empathy skills not only academically but also socially.

A person who has high intelligence (IQ), social empathy, high emotional intelligence (EQ), and spiritual intelligence (SQ) will likely help our country a better place to live in particularly amid the current pandemic crisis. Many social sciences graduates encounter a lack of social skills, given that their absence in various social activities within the 
community or beyond (Syaodih, 2018, p. 2). Since the ineffective learning model in most schools generates social misfit among students' learning progress besides, an insufficient amount of creativity in processing information (Fauziah et al, 2007, p. 282).

Regarding the context and goals of the social sciences learning mentioned above, a compatible learning method is required to aim its essential outcome based on the given context. According to Kronberg and Griffin (2000) developing students' critical thinking skills can be done through problem-based learning method applications. In the U.S alone, the government urged the utilization of problem-based learning on its educational stages to prepare students for college life or higher educational institutions with a degree in STEM (Science, Technology, Engineering, and Mathematics Academy). The instructional base of STEM strategy, particularly Texas Science, Technology, Engineering, and Mathematics Academy (T-STEM) is problem-based learning and projectbased learning models (Odell et al., 2019).

Problem-based learning is defined as an active learning approach where the students collaborate in groups to understand and solve complex and unstructured problems (Lu et al., 2014). The students have to share ideas, knowledge, solutions, and give constructive logical arguments in solving disorganized and jumbled decided problems (Lu et al., 2014). Marpaung (2005) asserted that the utilization of PBL roots back in the problem-solving method. Numerous claims of PBL are convinced that it can boost students' problem-solving skills (Gijnels et al., 2005). Similarly, this method benefits students' self-efficacy, increases students' performance in the classroom Allen et al., 2011). This method also can be applied as the core curriculum competencies for several lecture subjects (Alrahlah, 2016).

Campbell \& Norton (2009) affirmed that PBL develops an in-depth learning approach. Correspondingly, PBL is believed increasing students classroom performance, learning motivation, critical thinking skills, and 
academic achievement (See Alita et al., 2019; Anindyta \& Suwarjo, 2014; Anugraheni, 2018; Darmawan, 2010; Jailani \& Retnawati, 2016; Moner \& Gunansyah, 2013; Nafiah \& Suyanto, 2014; Rahmadani \& Anugraheni, 2017; Rahmasari, 2016; Samiadji, 2013; Setyorini et al., 2011; Sumitro H et al., 2017; Susanti \& Suwu, 2016; Widyaningrum \& Gregorius, 2013). Various experts argue that there is no empirical evidence on the significance of PBL in increasing students' classroom performance, at least at the rate of sufficient resources in PBL curriculum development. Hence, Colliver (2000) mentioned the insignificant relationship between learning theory and research (basic and applied research).

According to previous studies concerning social sciences learning that applied the PBL approach has prompted this research employing a metaanalysis approach. To best of author's knowledge, there was scarce empirical evidence has been garnered on meta-analysis study of problembased learning methods. Besides, this article is focused on the effectiveness of PBL in social sciences learning at elementary school (SD) and middle school (SMP). The effectiveness of PBL is measured based on the social sciences average achievement score and the average value of influenced aspects in PBL applications such as motivation and IQ.

\section{THEORETICAL BASES}

\section{The effectiveness of problem-based learning}

Problem-based learning refers to a learning model that trains scientific reasoning (Noly \& Wulandari, 2018, p. 33), the students will be able to identify common sense to make an appropriate decision in solving the problem. Otherwise, PBL also contains ill-structured or open-ended which is projecting the practical problem through learning stimuli (Fogarti, 1997, p. 54). Meanwhile, Duch (1995) stated that PBL refers to students' learning efficacy where students are challenged to study efficiently. 
PBL has four distinctive characteristics, the following will be mentioned below based on Savoie and Hughes (1994) as quoted from Wena (2010): Firstly, it begins with a problem statement; secondly, the interconnection of various disciplines; thirdly authentic investigation; fourthly, collaborative work. PBL emphasized complex problems without absolute right answers (Hmelo-Silver, 2004). As students solving unstructured complicated problems, they start developing common sense skills and independent learning initiatives. Consequently, Lu et al. (2014), stated that PBL improved students' ability to transfer new insights to understand complex problems and to comprehend coherent knowledge.

According to Duch et al. (2001), PBL emerged students' critical analysis skills, practical problem-solving, teamwork, and communicative skills either spoken or written. Gijbels et al. (2005) reported that PBL has a positive effect on principle knowledge that connects to a concept. Furthermore, Dohcy et al. (2003) found that students who are exposed to PBL learning presumably have sharp memories and highly creative.

\section{Social Science Learning}

Social studies term was first coined by the committee of social studies in the U.S. Nonetheless, social studies or social sciences refer to human sociocultural aspects (Lubna et al., 2010, p. 6). It was designed to understand certain social phenomena.

According to the goals of social sciences learning the students not only accomplish the social skills to understand social phenomena but also individual skills to strive in the community as social beings. Ideally, social sciences learning material is designed in two-dimensional aspects, theoretical and practical dimensions; conceptual and factual dimensions. The theoretical dimension originated from basic concepts of social sciences (history, geography, economics, sociology, anthropology, politics, socio- 
psychology) which is the core of social studies. While the practical dimension is the embodiment of practical conditions within society.

Practical social concepts are valuable to our social life where the community solves the problem together. PBL is relevant to prepare students' real-life game changer situations in the future.

As quoted in Bining \& Bining (1952) social sciences referred to the integrative study of social disciplines and humanity and aimed to improve community social competence in a democratic and plural environment (Tasrif, 2008, p. 1). Correspondingly John Jarolimek (1997, p. 224) asserted that "the social studies as... subject-matter content from the social science, history, sociology, political science, social psychology, anthropology, and economics. The social studies have been defined as " those portion of the social science... selected for instructional purpose". Winataputra (2005, p. 4), assumed that social sciences learning is a fusion of social discipline, state ideology, that is organized into the other social problems scientifically and psychologically at elementary and middle stage educations.

Thus, social sciences learning have defined as a broad discipline and comprehensive. As to why it compressed into an interdisciplinary approach at each educational stage. It is no surprise that social sciences are also defined as human knowledge and its social life aspects (Sumaatmadja, 1980, p.6). Particular views on the social science context learning may lead to various social interpretation in its application. Specifically, in the Indonesian context, there are many different terms of social studies at distinct educational levels, such as history, geography, economics, sociology, anthropology, accountancy, politics for the higher education stage. Unlike other subjects such as mathematics using the same terms unless the different levels of educations. 


\section{Meta-Analysis}

Meta-analysis is a statistical analysis that combines multiple empirical studies. This statistical method was first developed by Karl Pearson in 1904 on medical studies. Whilst, on the 1970s this method was adapted for educational field purposed (e.g. Glass et al., 1981; Glass, 1982; Schmidt, 1994; and Hunter \& Schmidt, 2004). Glass described that meta-analysis is a qualitative approach using several data and measured using the statistical method from huge sample to complete the research (Glass, 2016; in comparison to Sukamto, 1989, 1991, p. 50). It is required to use the same topic references in a meta-analysis study.

There are several steps in a meta-analysis study according to (Merriyana A., 2006), as mentioned in the following table below:

Tabel 2. Several steps in a meta-analysis study

\begin{tabular}{ll}
\hline Stages & Activity \\
\hline Step 1 & Decide a problem or topic that will be studied \\
Step 2 & Decide the period of the analysis unit or data source \\
Step 3 & Lookup for the sorted topic that will be studied. \\
Step 4 & Read title and abstract of related topics \\
Step 5 & Focus on the problem statement, method, and research outcome. \\
Step 6 & Categorize the research based on the paradigm \\
Step 7 & $\begin{array}{l}\text { Compare all the research based on the category, and then find the } \\
\text { standard deviation using effect size equation. }\end{array}$ \\
Step 8 & Analyze the conclusion by examining the study results. \\
Step 9 & Draw the meta-analysis conclusion according to points 7 and 8. \\
\hline
\end{tabular}

Meta-analysis coding can easily help the process of finding the analysis units. It is important to use detailed and good related topics that provided complete statistical analysis. This matter is based on Glass (1981) that the weakness of meta-analysis is we cannot qualify good research out of its quality. A researcher who conducts a meta-analysis study is required to analyze, sort the qualified references particularly based on the methods for the proper publications in the future. 


\section{METHODE}

This research employed a quantitative approach with a meta-analysis method. Meta-analysis refers to the use of the same related topics which is a problem-based learning model on social sciences at elementary and middle-level educations (SD and SMP). 4 journals out of 9 of the same topic studies were referenced to determine the analysis unit based on the representative ones. As from the four analysis units, 6 sub-unit then settled. The researcher used the data coding sheet as the main instrument to complete the information on the influence of problembased learning.

Glass' effect size formula is employed to measure the standard deviation, the formula is as written below:

$$
\Delta=\frac{\overline{\mathrm{X}}_{\mathrm{E}} \overline{\mathrm{X}}_{\mathrm{K}}}{\mathrm{S}_{\mathrm{k}}}
$$

Where:

$$
\begin{aligned}
\Delta & =\text { effect size } \\
\overline{\mathrm{X}}_{\mathrm{E}} & =\text { Average of experiment group. } \\
\overline{\mathrm{X}}_{\mathrm{K}} & =\text { Average of the control group. } \\
\mathrm{S}_{\mathrm{k}} & =\text { Standard deviation of the control group }
\end{aligned}
$$

The calculation of this equation was conducted to measure the related variables in problem-based learning. While to calculate the average of the magnitude phenomenon another equation was employed:

$$
\bar{\Delta} \pm=\frac{1.96 x \sigma_{\bar{\Delta}}}{\sqrt{n}}
$$

Where:

$$
\begin{array}{ll}
\bar{\Delta} & =\text { average of effect size } \\
\sigma_{\Delta} & =\text { standard deviation effect size } \\
1,96 & =\text { value of } \mathrm{Z}(a=0,05) \\
\mathrm{N} & =\text { total of sub-analysis }
\end{array}
$$




\section{RESULT AND DISCUSS}

According to the result of the average value of the magnitude phenomenon of problem-based learning that involved the other variables is displayed below.

Tabel 3. The average value of the PBL magnitude of the phenomenon with the other variables

\begin{tabular}{cccccccc}
\hline Statistic & $\mathbf{1}$ & $\mathbf{2}$ & $\mathbf{3}$ & $\mathbf{4}$ & $\mathbf{5}$ & $\mathbf{6}$ & Mean \\
\hline $\mathbf{N}$ & 39 & 30 & 20 & 20 & 60 & 60 & 38,16 \\
$\boldsymbol{\Delta}$ & 1,10 & 1,39 & 0,43 & 1,05 & 0,45 & 0,35 & 0,795 \\
$\boldsymbol{\sigma}_{\Delta}$ & 6,29 & 3,60 & 2,94 & 5,67 & 12,76 & 10,8 & 7,01 \\
$\boldsymbol{\sigma}_{\Delta} / \Delta$ & 5,72 & 2,59 & 6,84 & 5,40 & 28,36 & 30,86 & 13,295 \\
\hline
\end{tabular}

Where:

1 = Problem-based learning only

2 = Problem-based learning and high motivation

3 = Problem-based learning and low motivation

4 = Problem-based learning and integrated learning

5 = Problem-based learning and high IQ

6 = Problem-based learning and low IQ

Data on table 3 showed that the average value of the magnitude phenomenon of problem-based learning is high when it paired with high motivation and followed by learning method without the other variables, problem-based learning and integrated learning, problem-based learning and high IQ, problem-based learning and low motivation, and the lowest is pointed by low IQ variable. Variance coefficient of problem-based learning $(1,2,3,4,5$, and 6$)$ are 572\%, 259\%, 540\%, 2836\%, and 3086\%. Thus, the spread in data towards the average of effect size with the other variables involved and problem-based learning the order average of each magnitude phenomenon is $(2,1,4,5,3$, dan 6$)$. 
This meta-analysis study consists of 4 analysis units coupled with 6 sub-unit. The effect size value reached at number 0,795. This value means the utilization of problem-based methods on elementary and middle school students in the social sciences class has been significantly effective compared to the result of the experiment groups.

This current study corresponds to Lu et al. (2014) where PBL has significant influence to enhance student's achievement to polish their critical thinking skills in contrast to the conventional learning method.

It is also simply summed up that this method applies to all educational stages, specifically in the social sciences learning context.

The result of each subunit showed various average values of effect size. The highest value hits at number 1,39 which referred to the comparability of problem-based method and conventional learning one. Whilst, the lowest number reached at 0,35 that students who have lower intelligence performed poorly on the problem-based learning in comparison to the conventional method.

The finding results above revealed that high intelligence students presumably perform better in problem-based learning compared to the lower intelligence and low motivated ones. In comprehending problembased learning the students should have prior skills of organizing problems apart from a mere discipline. Inconsequent to the application of this learning model, high responsibility is mandatory for students to learn independently beyond the classroom. Highly motivated learners are also prepared to follow this method. Following the requirements of PBL where students have to redemonstrate what they have learned in the previous classes. In conclusion, it is necessary to consider the students' intelligence and motivation beforehand. 


\section{CONCLUSION}

It is showed that highly motivated students have greater chance to be compatible or to be prepared for problem-based learning method compared to their low motivated peers, also this method fits best to students who possessed higher intelligence rather than who do not.

This learning method applies to all educational stages; from primary to tertiary schools. There was no significant difference in its all stage application given that it is utilized based on syntax.

To sum up, this learning method provided an alternative learning model for educators, particularly in developing students' critical thinking skills and problem-solving skills as well.

\section{REFERENCES}

Alita, K. U., Koeswanti, H. D., \& Giarti, S. (2019). Penerapan Model Problem Based Learning untuk Meningkatkan Kemampuan Berpikir Kritis Siswa Kelas V SDN Ledok 5 Tahun Pelajaran 2018/2019. Jurnal Basicedu, 3(1), 169-173. https://doi.org/10.31004/basicedu.v3i1.97

Allen, D. E., Donham, R. S., \& Bernhardt, S. A. (2011). Problem-based learning. New Directions for Teaching and Learning, 2011(128), 21-29. https:/ / doi.org/10.1002/tl.465

Alrahlah, A. (2016). How effective the problem-based learning (PBL) in dental education. A critical review. The Saudi Dental Journal, 28(4), 155-161. https:// doi.org/10.1016/j.sdentj.2016.08.003

Anindyta, P., \& Suwarjo, S. (2014). Pengaruh Problem Based Learning Terhadap Keterampilan Berpikir Kritis dan Regulasi Diri Siswa Kelas V. Jurnal Prima Edukasia, 2(2), 209-222. https://doi.org/10.21831/ jpe.v2i2.2720

Anugraheni, I. (2018). Meta Analisis Model Pembelajaran Problem Based Learning dalam Meningkatkan Keterampilan Berpikir Kritis di 
Sekolah Dasar [A Meta-analysis of Problem-Based Learning Models in Increasing Critical Thinking Skills in Elementary Schools]. Polyglot: Jurnal Ilmiah, 14(1), 9-18. https:/ / doi.org/10.19166/pji.v14i1.789

Campbell, A., \& Norton, L. (2009). Learning, Teaching and Assessing in Higher Education: Developing Reflective Practice. Learning Matters Ltd.

Colliver, J. A. (2000). Effectiveness of Problem-based Learning Curricula: Research and Theory. Academic Medicine, 75(3), 259-266.

Darmawan. (2010). Penggunaan Pembelajaran Berbasis Masalah dalam Meningkatkan Kemampuan Berpikir Kritis Siswa pada Pembelajaran IPS di MI Darrusaadah Pandeglang. Jurnal Penelitian Pendidikan, 11(2), 21-29.

Dochy, F., Segers, M., Van den Bossche, P., \& Gijbels, D. (2003). Effects of problem-based learning: A meta-analysis. Learning and Instruction, 13(5), 533-568. https:/ / doi.org/10.1016/S0959-4752(02)00025-7

Duch, B. J. (1995). Problems: A Key Factor in PBL. About Teaching 50, 7-8, $50,7-8$.

Duch, B. J., Groh, S. E., \& Allen, D. E. (Eds.). (2001). The Power of ProblemBased Learning (1 edition). Stylus Publishing.

Fauziah et al, T. (2007). Pembelajaran IPS SD/MI. Universitas Syiah Kuala Banda Aceh \& Universitas Muhammadiyah Banda Aceh.

Fogarti, R. (1997). Problem Based Learning and Other Curriculum Models for the Multiple Intelligences Clasroom. Sky Light.

Gijbels, D., Dochy, F., Bossche, P. V. den, \& Segers, M. (2005). Effects of Problem-Based Learning: A Meta-Analysis From the Angle of Assessment: Review of Educational Research. https:/ / doi.org/10.3102/ 00346543075001027

Glass, G. V. (1982). Meta-analysis: An approach to the synthesis of research results. Journal of Research in Science Teaching, 19(2), 93-112. https://doi.org/10.1002/tea.3660190202 
Glass, G. V. (2016). Primary, Secondary, and Meta-Analysis of Research1: Educational Researcher. https://doi.org/10.3102/0013189X005010003

Glass, G. V., Smith, M. L., \& McGaw, B. (1981). Meta-analysis in social research. Sage Publications, Incorporated.

Hmelo-Silver, C. E. (2004). Problem-Based Learning: What and How Do Students Learn? Educational Psychology Review, 16(3), 235-266. https://doi.org/10.1023/B:EDPR.0000034022.16470.f3

Hunter, J. E., \& Schmidt, F. L. (2004). Methods of meta-analysis: Correcting error and bias in research findings. Sage.

Jailani, \& Retnawati, H. (2016). Keefektifan Pemanfaatan Perangkat Pembelajaran Berbasis Masalah untuk Meningkatkan HOTS dan Karakter Siswa. Jurnal Pendidikan Dan Pembelajaran, 23(2), 111-123.

Jarolimek, J. (1997). Social Studies in Elementery Education. Macmian Publishing Cp. Inc.

Kronberg, J. R., \& Griffin, M. S. (2000). Analysis Problems: A means to develop students' critical-thinking skills. Journal of College Science Teaching, 29(5), 348-352.

Lu, J., Bridges, S., \& Hmelo-Silver, C. E. (2014). Problem-Based Learning. In R. K. Sawyer (Ed.), The Cambridge Handbook of the Learning Sciences (2nd ed., pp. 298-318). Cambridge University Press. https://doi.org/ 10.1017/CBO9781139519526.019

Lubna et al. (2010). Ilmu Pengetahuan Sosial 1. Amanah.

Marpaung, R. R. T. (2005). Penggunaan Lembar Ke $\neg$ giatan Pembelajaran Berbasis Masalah (LK-PBM) sebagai Asesmen Alternatif Untuk Meningkatkan Kemampuan Berpikir Kritis dan Hasil Belajar Peserta didik Kelas V SMP Laboratorium Universitas Negeri Malang [Thesis]. Universitas Negeri Malang.

Merriyana A., R. (2006). Meta Analisis Penelitian Alternatif bagi Guru. Jurnal Pendidikan Penabur, 6. 
Moner, \& Gunansyah, G. (2013). Model Pembelajaran Berdasarkan Masalah (PBM) untuk Meningkatkan Hasil Belajar pada Sekolah Dasar. JPGSD, 1(2), 1-10.

Nafiah, Y. N., \& Suyanto, W. (2014). Penerapan model problem-based learning untuk meningkatkan keterampilan berpikir kritis dan hasil belajar siswa. Jurnal Pendidikan Vokasi, 4(1), Article 1. https://doi.org/10.21831/jpv.v4i1.2540

Noly, S., \& Wulandari, F. E. (2018). Model Problem Based Learning (PBL) dalam Melatih Scienific Reasoning Peserta didik. Jurnal Penelitian Pendidikan IPA, 3(1).

Odell, M., Kennedy, T., \& Stocks, E. (2019). The Impact of PBL as a STEM School Reform Model. Interdisciplinary Journal of Problem-Based Learning, 13(2). https:/ / doi.org/10.7771/1541-5015.1846

Rahmadani, N., \& Anugraheni, I. (2017). Peningkatan Aktivitas Belajar Matematika Melalui Pendekatan Problem Based Learning bagi Siswa Kelas 4 SD. Scholaria: Jurnal Pendidikan dan Kebudayaan, 7(3), 241-250. https://doi.org/10.24246/j.scholaria.2017.v7.i3.p241-250

Rahmasari, R. (2016). Penerapan Model Pembelajaran Problem Based Learning Untuk Meningkatkan Hasil Belajar IPA Kelas IV SD. Jurnal Pendidikan Guru Sekolah Dasar, 5(36), 3456-3465.

Samiadji. (2013). Penerapan Model Pembelajaran Berdasarkan Masalah untuk Meningkatkan Hasil Belajar Siswa pada Mata Pelajaran IPS Kelas IV SDN Jemurwonosari II/525 Surabaya. Jurnal Penelitian Pendidikan Guru Sekolah Dasar, 1(1), 1-8.

SCHMIDT, H. G. (1994). Problem-based learning: An introduction. Instructional Science, 22(4), 247-250. JSTOR.

Setyorini, U., Sukiswo, S. E., \& Subali, B. (2011). Penerapan Model Problem Based Learning Untuk Meningkatkan Kemampuan Berpikir Kritis Siswa SMP. Jurnal Pendidikan Fisika Indonesia, 7, 52-56. 
Soekamto, T. (1989). Keefektifan Strategi Instruksional: Suatu Meta Analisis. Lemlit IKIP Jakarta.

Soekamto, T. (1991). Meta Analisis di dalam Penelitian Sosial. Gramedia Pustaka Utama.

Sumaatmadja, N. (1980). Metodologi Pengajaran Ilmu Pengetahuan Sosial (IPS). Alumni.

Sumitro H, A., Setyosari, P., \& Sumarmi, S. (2017). Penerapan Model Problem Based Learning Meningkatkan Motivasi dan Hasil Belajar IPS. Jurnal Pendidikan: Teori, Penelitian, dan Pengembangan, 2(9), 11881195. https://doi.org/10.17977/jptpp.v2i9.9936

Susanti, A. E., \& Suwu, S. E. (2016). Penerapan Pembelajaran Berbasis Masalah untuk Meningkatkan Ketrampilan Berpikir Kritis Siswa Kelas IX dalam Pelajaran Ekonomi [Problem-Based Learning Implementation to Increase Grade IX Students' Critical Thinking Skill in Learning Economics]. Polyglot: Jurnal Ilmiah, 12(1), 66-81. https:/ / doi.org/10.19166/pji.v12i1.383

Syaodih, E. (2018). Pengembangan Model Pembelajaran Kooperatif untuk Meningkatkan Keterampilan Sosial. FKIP Universitas Langlang Buana. Tasrif. (2008). Pengantar Pendidikan Ilmu Pengetahuan Sosial. Genta Press. Trianto. (2007). Model Pembelajaran Terpadu Dalam Teori dan Praktek. Prestasi Pustakaraya.

Wena, M. (2010). Model Pembelajaran Inovatif Kontemporer Suatu Tinjauan Konseptual Operasional. Bumi Aksara.

Widyaningrum, R., \& Gregorius, J. (2013). Penerapan Model Pembelajaran Berdasarkan Masalah untuk Meningkatkan Hasil Belajar Siswa pada Pembelajaran IPS Sekolah Dasar. JPGSD, 1(1), 1-11.

Winataputra, U. (2005). Materi dan Pembelajaran IPS SD. UT. 